\title{
Germany follows Britain in dumping fast breeder
}

Munich. Europe's fast-breeder reactor programme is on the verge of collapse because Germany has joined Britain in pulling out of its commitment. France is now the only country with a continuing interest in the programme, and it may not be able to carry on alone.

On 8 December, Germany announced that funding for fast breeder research at the Karlsruhe Nuclear Research Centre will not be renewed after 1993. Nuclear power is controversial in Germany, which has shown a strong commitment to the environment, plutonium in fast-breeder reactors. Thus it was no surprise that when the British government decided to abandon the 1984 trilateral agreement to develop a European fast-breeder reactor (see Nature 360, 93; 1992), Germany reversed its own position, expressing its "respect for the decision" and saying that it was a "consequence of an energy policy appropriate to the times".

The decision is a great disappointment to researchers, who say that a research programme that took years to build up has been the future looks very sad", says Willy Marth, executive director of the management group for the European fastbreeder programme. "Everything we've worked for has just been brushed away."

The anticipated cost of the project was an important factor for both countries, trying desperately to trim spending. French officials acknowledge that the outlook for fast breeders, which looked bright when the joint venture was proposed eight years ago, is much dimmer now. But Philippe Hammer, deputy director of nuclear reactors at the French Atomic Energy Commission, says that the commission hopes to obtain enough additional money from its other the utilities company EDF, to be able to go it alone, although at a slower pace. He believes that fast breeders are an inevitable part of the long-term future of energy and no issue is more sensitive than the use of dismantled overnight. "From 1994 onwards, sources of funding, the government and

generation in Europe.

The loss of British and German support also threatens reprocessing facilities in France and Britain. German's decision caused dismay at Britain's Sellafield plant, with reports that two German companies, RWE and Pilz, were planning to renege on their current reprocessing contracts.

The rumours were fuelled by continuing debates in the German parliament about the atomic energy law. The law, passed in the 1970 s, requires all spent fuel to be reprocessed; at the time, it was believed to be the most efficient way to dispose of radioactive fuel. But times have changed and the law is expected to be modified, probably in 1994 , to allow industry to choose between reprocessing and storage.

The utilities companies have been quick to contradict reports that they want to pull out immediately. "Whatever happens, we will be fulfilling our contracts with THORP at Sellafield and with the French reprocessing plant Cogema", says an RWE spokesman, who explained that the rumour stems from a misreading of a letter from the industry to Chancellor Helmut Kohl, agreeing simply to take part in talks on the future of nuclear power in Germany. The contract is unlikely to be renewed upon expiring in 2000 , however, as storage has become cheaper than reprocessing.

The long-term feasibility of THORP is threatened by this development, particularly because its second line of activity may also be doomed. Reprocessing plants are pinning their hopes on the sale of reprocessed plutonium in fuel rods called MOX elements, which can be burnt in conventional light-water reactors. But even this market is shrinking as nuclear power falls out of favour. Britain has no plans to build any more light-water reactors (it has only one, Sizewell B) and Germany looks increasingly likely to make a political decision against using the plutonium-based fuel in its reactors.

Alison Abbott

\section{EC expected to rearrange research portfolio}

Munich. The European Commission was expected this week to agree to divide its research programme between two commissions. Meeting in Strasbourg, the Council of Ministers is prepared to shift industrial research, along with high-profile innovation and technology transfer programmes such as SPRINT, into a separate commission to be headed by Germany's former minister of economic affairs, Martin Bangemann. Filippo Pandolfi has for the last few years

\section{Collins to head NIH genome centre, open laboratory}

Washington. Officials at the US National Institutes of Health (NIH) have succeeded in recruiting Francis Collins, a geneticist at the University of Michigan, to become director of NIH's National Center for Human Genome Research. Collins, who expects to move to the NIH campus in mid1993, will also form an intramural research programme at the centre, which until now has only funded genome research around the country.

Collins has long been the leading candidate to succeed James Watson, who resigned last spring after questions were raised about his holdings in various biotechnology companies (see Nature 356, 549;

1992). Much of

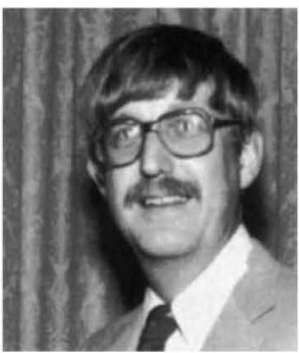
the speculation has centred on whether NIH would be able to make its offer attractive enough to lure Collins away from Michigan, where he has worked since 1984. The recruitFrancis Collins ment campaign appeared to suf-

fer a setback in October, when Congress cut by nearly 50 per cent the $\$ 20$-million discretionary fund that Bernadine Healy, the NIH director, had planned to draw on to provide a new laboratory for Collins. But Collins, whose Michigan laboratory costs approximately $\$ 1.5$ million a year to run, says that the discretionary fund will be big enough to support his new laboratory.

$\mathrm{NIH}$ is expected to request additional money for the genome centre in its budget requesi for fiscal year 1994, which begins on 1 October 1993. Collins's appointment, although a virtual certainty, must be approved by the director of the Department of Health and Human Services, NIH's parent organization.

Collins is expected to bring with him much of his research team, which numbers 25. A co-discoverer in 1989 of the gene for cystic fibrosis, Collins will probably occupy laboratory space vacated by geneticist Craig Venter, who left NIH last July to direct a new, private company to do large-scale gene sequencing (see Nature 358, 95; 1992). Collins also plans by 1995 to add 20 principal investigators and their research teams to the centre to work on gene discovery, a field largely neglected on the NIH campus, and on gene therapy.

Traci Watson 